\author{
Research Article \\ (C) 2021 M. A. Alkohaiz and H. A. bin Shalhoub. \\ This is an open access article licensed under the Creative Commons \\ Attribution-NonCommercial 4.o International License \\ (https://creativecommons.org/licenses/by-nc/4.o/)
}

Received: 27 October 2020 / Accepted: 10 December 2020 / Published: 17 January 2021

\title{
Structuring Youth Councils in Saudi Arabia: A Forecast Study
}

\author{
Mohammed Abdurahman Alkohaiz
}

Social Studies Department, College of Arts, King Saud University, Riyadh 12372, Saudi Arabia

\section{Haifa Abdulrahman bin Shalhoub}

Social Planning Department, College of Social Work,

Princess Nourah bint Abdulrahman University, Riyadh 11564, Saudi Arabia Kingdom

DOI: https://doi.org/10.36941/ajis-2021-0oo9

\begin{abstract}
Youth is one of the most substantial pillars of community development. The study investigates the optimal structure of youth councils in Saudi Arabia. And it establishes the necessary regulations by setting targets, tasks, conditions of membership, and developing a unified proposal for these councils. The primary study tool was a questionnaire developed by researchers were used to assess the studied parameters. They were distributed to (413) young men at King Saud University in Riyadh, Saudi Arabia, aged (18-34) years. According to the analytical approach, it is a forecast study. The study results showed that the optimal structure of these councils' includes: First, the prince of the region or the governor as a president. Second, the rector as a vicepresident. Finally, the commission is equally male and female. While the council objectives: First, take advantage of youth proposals, capacities, and intellectual property. Secondly, youth participation in the discussion, determination of their requirements, and decision-making. Also, it identified a set of tasks: Encouraging creative and talented youth to achieve national accomplishment and motivating them to take on their responsibilities in serving their community. As for the terms of the Council's membership, members must be between 18 and 30 years, and the name of the office shall be two years and nominated by government educational bodies. There should be a responsible body for structuring youth councils regions, increasing youth councils, and meetings between them in a periodic manner among different countries to exchange experiences and improve performance.
\end{abstract}

Keywords: Youth Councils, Saudi, Structuring, a Forecast Study

\section{Introduction}

Civilizations can only develop through the effective and fruitful planning of youth in any society, by supervising their realistic environment, developing their social participation, and planning for their future with a precise awareness of their realities and challenges. More specifically, by engaging them systematically in decision-making and listening to their views (Forde \& Martin, 2016). Therefore, organizing their participation through official and regular councils of their matches the successful 
international and Arab experiences in this field, in line with the importance and size of this population category. For instance, UAE "United Arab Emirates" Youth Councils and Youth Councils in Britain (AlRasheed, 2017). Accordingly, the number of Saudi youth (male and female) in Saudi Arabia, who aged $15-34$ years, reached $(7,623.336)$ individuals, or $36.7 \%$ of the total population of Saudi Arabia in 2019 (Statistics, 2019). All in all, this energetic and ambitious category is fundamental for national investment and sustainable development in Saudi Arabia.

Youth is the nation's hope, goal, and the engine for community development, so every investment made to gain youth values and righteous trends is a total return, making them the impetus of development goals. Another contributing factor, youth is one of the most vital hubs of community development in any society, so societies drive them toward productivity and innovation (Seibert \& Seale, 2006). In particular, by providing education, training, employment, and participation in the development process to meet global competition, to keep pace with rapid contemporary technological developments, and to participate with decision-makers in policy-making and discussion of issues that are specific to society in general and youth in particular (Muhammad, 2014).

The Kingdom's 2030 vision aims to activate the youth's role in society, and it has given the utmost significance, as youth constitute $70 \%$ of Saudi society. Besides, young men have an essential role in sustaining the national economy. For this reason, we should create appropriate jobs for them, enhance women's participation in the labor market, yield functional sustainability (government, 2020). Furthermore, provide training courses and scientific programs that will qualify and enable them to engage in work, Compete in the labor market, and launch a business, economic, and social projects. Furthermore, support self-employment, entrepreneurship, and small and medium-sized enterprises and facilitate their established procedures. Also, provide youth counseling, thereby accelerating the pace of development revival In different areas. Hence, build a vibrant and robust economy based on the human element and diversify income sources, thus achieving economic prosperity and embody the post-oil economy stage in the Kingdom (Al-Rasheed, 2017).

The youth councils aim to deepen the spirit of loyalty and belonging, monitor youth issues and problems, and propose appropriate solutions. Augsberger et al. (2018) state that in 2007 the National League of Cities-NLC defined youth councils as formal bodies composed of young people (usually aged 16 to 18 ) who advise decision-makers and are officially elected. Clearly, youth participation in government is vital for sufficient understanding and solutions to issues at both the community and state levels. In turn, this helps to achieve positive results for youth development (Akiva et al., 2014). Thus, promote democracy in general (Nairn et al., 2006). Another critical point is that the councils' structure and role differ from city and state to others. In some instances, they provide advice on proposed legislation, State budget expenditures, funding of youth programs, and drafting and proposing legislation, as required, for example, by the Youth Council of Marine. The state's youth councils give young people a prominent role in the political decision-making process (Martin et al., 2007).

\section{Theoretical Framework}

\subsection{First: History of youth councils}

Jostyn (1945) indicate that the Youth Council's earliest reference in the United States goes back to Manhasset Youth Council 1943. Whereas, the Council was an integral part of the municipal entertainment committee, establishing to meet the youth's needs in spending their leisure timeinstead, vandalism and other activities that are not beneficial to them or their community during that period. However, recent research (Collins et al., 2018) show some similarities between the early form of youth councils and their current practice, as youth councils are often an integral part of government departments' humanitarian services, including entertainment, health education, and education. There is some interest in understanding youth councils' potential to support youth development and participate in youth-centered political decision-making. But officially, city-level youth committees 
were first introduced in the mid-199os, such as the San Francisco City Youth Committee and the Houston City Youth Committee, followed by establishing the first state youth legislative Council in Maine in 2001(Conner \& Cosner, 2016). Meanwhile, in 2007, 12 states and 140 American cities have established youth councils or committees to advise decision-makers in the U.S. government, local state, or city level on youth-related policies and legislation (Martin et al., 2007). And in 2012, the National Council of Young Leaders was launched, which was created to share young people's views and priorities in the policy area for their category with federal legislators (Conner \& Cosner, 2016).

In Saudi Arabia, district youth councils, operating in isolated islands based on different regulatory authority, are in place before establishing their uniform regulation in 2019. More specifically, the district youth councils and its committees have been formed not long ago, by a remarkable initiative of some of the regions' Emirates. To recognize the need of young people, believe that they are a vital social force as a significant social sector in society, and invest in developing their regions and overall development. They are supervised directly by the district Emirates. For instance, the Mecca Youth Council, the Eastern region Youth Council, the Asir Youth Council, the Jazan Youth Council, the Al Baha region Youth Council, the Juf Youth Council, and the Ha'il, the Qassim Youth Council, and the Northern border region Youth Council (Al-Sharari, 2017). In addition to many provincial youth committees and councils. In particular, these councils, and their events, may be different from their work, achievements, support, and distribution, and are vague in their terms of reference and organization. For this reason, we should strengthen the crucial role of the district youth councils and optimize them according to comprehensive regulatory frameworks, consistent with the state's policies and the Kingdom 2030 vision, which start establishing their unified regulations and still require many regulatory steps (Al-Sharari, 2017; government, 2020). The Shura Council in Saudi Arabia approved the draft unified regulation of the region youth councils in 2019, where the first meeting was at the youth councils forum of delegation heads from the district youth councils in the Kingdom held in the Al-Jouf area (Al-Azmi, 2019).

\subsection{Second: the importance and objectives of youth councils:}

USAID and EQUIP3 (2009) address the importance of youth councils. Notably, councils' implications can have from concrete local projects to more significant behavioral or societal changes. For example, new toilets and cleaner streets. Such as increased self-esteem, youth policy development. Therefore, they emphasize that involving young people in these councils improves confidence, self-respect, and identifies their goals. Thus, involving young people in these practical councils is highly internally satisfied and provides young people with opportunities to acquire new skills. Another example is rhetoric, fundraising, improved leadership skills, and their ability to plan and manage projects to participate in a youth Council. Additionally, help to transfer many of the skills gained through participation in youth councils to other contexts. Moreover, youth councils strengthen intergenerational dialogue and enhance their image in state policy and decision-makers' eyes. Accordingly, there are global success experiences for the Youth Council, where many youth councils run projects to improve their communities. While these projects usually target youth, some benefit the entire population (Matthews, 2001). Another goal of youth councils is to communicate with governments and the media to link the youth requirements they represent. Additionally, an attempt to make these councils reflect the most extensive representation category within all sects' society. More specifically, these councils' purpose is not only local, but it might also be international by creating cross-country youth initiatives to establish partnership projects among other youth councils, including training, capacity-building, and exchange of experiences, as in the Saudi-UAE Youth Council case. In short, this issue may be a role for awareness about development issues between Young people in their country (Seibert \& Seale, 2006). 


\subsection{Third: Local, regional, and international experiences of youth councils}

The following presentation will discuss some models of youth councils, including the idea, vision, objectives, tasks, and membership terms as follows:

Table 1. Saudi-UAE Youth Council

\begin{tabular}{|c|c|}
\hline Idea & $\begin{array}{l}\text { The initiative "establishing the Saudi-UAE Youth Council" is an implementation of the } \\
\text { recommendations of the Saudi-UAE Coordination Council. On the Saudi side. It was chaired by } \\
\text { His Royal Highness Prince Mohammed bin Salman bin Abdul Aziz Al Saud, Crown Prince, Deputy } \\
\text { Prime Minister, Minister of Defense, and Chairman of the Council for Economic Affairs and } \\
\text { Development. O n the UAE side, chaired by his Highness Sheikh Mohammed bin Zayed Al } \\
\text { Nahyan, Crown Prince of Abu Dhabi, Deputy Commander-in-Chief of the Armed forces, and } \\
\text { Chairman of the Executive Council of Abu Dhabi, with ministers and officials from both } \\
\text { countries. Therefore, to activate the Saudi-UAE youth's role in achieving the desired goals, the } \\
\text { Saudi-UAE Youth Council will deliver youth ideas to decision-makers from both countries. }\end{array}$ \\
\hline Vision & $\begin{array}{l}\text { They are creating a youth generation able to lead the future through a leadership environment } \\
\text { that fulfills young people's aspirations and enhances their abilities. }\end{array}$ \\
\hline Message & $\begin{array}{l}\text { They seek to empower young people to be a vital part of decision-making and future direction } \\
\text { through sustainable opportunities in the two countries' vision goals. }\end{array}$ \\
\hline Objectives & $\begin{array}{l}\text { - Stimulate youth partnerships and exchange ideas among them in both countries. } \\
\text { - Invest their vitality in different areas and sectors and contribute and effectively participate in } \\
\text { developing future scenarios. } \\
\text { - Encourages them to devise development initiatives to meet the challenges of the future. }\end{array}$ \\
\hline Functions of the & $\begin{array}{l}\text { The Council identified seven themes on which the Saudi-UAE Youth Council is based: (Tourism, } \\
\text { education, media, culture and art, entertainment, entrepreneurship, and health). }\end{array}$ \\
\hline $\begin{array}{l}\text { Conditions of } \\
\text { Council } \\
\text { membership }\end{array}$ & $\begin{array}{l}\text { The candidate is nominated by completing the member's data form and being a member's } \\
\text { nationality (Saudi, UAE) with the official papers attached, some initiatives suggested by the } \\
\text { member, and his participation in other youth councils. }\end{array}$ \\
\hline & Its membership includes: \\
\hline Council & $\begin{array}{l}\text { - Her Excellency the Secretary of State for Youth Affairs of the United Arab Emirates. } \\
\text { - Assistant under-Secretary for Sustainable Development, } \\
\text { - Assistant Deputy-General for the G-2o. } \\
\text { - Ministry of Economy and Planning of Saudi Arabia. }\end{array}$ \\
\hline
\end{tabular}

Source: Saudi Emirati Youth, 2020

Table 2. Saudi Arabia's Al-Jouf Youth Council

\begin{tabular}{ll}
\hline Vision & The Council should be an incubator for young people to create a future that is fulfilling their \\
needs. For this reason, they achieve the goals of sustainable development. \\
Message \\
The Council provides diverse and sophisticated services to all society members through a \\
competitive youth work system within national responsibility and effective community \\
partnership. Also, the Board relies on the following values: honesty, transparency, initiative, \\
quality, belonging, being bobby, and teamwork. \\
- Involving young people in defining their requirements in a manner that is not incompatible \\
with Religious constants or state regulations, and promote the youth's belonging to the \\
homeland and leadership. \\
- They are deepening the confidence of young people in themselves and their society. \\
- The youth participates in volunteer work and utilization of their capabilities and skills in \\
serving the nation. \\
- Deepening sense of responsibility through reinforcing patriotism and social ties. \\
- Consolidating the principle of dialogue and strengthening youth ties. \\
- They are investing in young people's time to develop their skills and capabilities.
\end{tabular}


Functions of the There are special functions for each of the following subcommittees of the Council: The Council Constituent Committee of the Juf District Youth Council, the Committee on Information and Communication, the Committee on Public Relations, the Cultural Committee, the Voluntary Committee, the Health Committee, the Committee on Sports and the Hat, and the Vocational Training Committee.

Conditions of It is for all youth in the region who are aged 16-30 years.

\section{Council}

membership

Source: Jouf, 2020

Table 3. the Tabuk region Youth Council, Saudi Arabia

\begin{tabular}{|c|c|}
\hline Idea & $\begin{array}{l}\text { With endeavors and an ongoing effort, His Royal Highness Prince Fahd Bin Sultan Bin } \\
\text { Abdulaziz Al Saud established the Tabuk region Youth Council. Consequently, the energies and } \\
\text { abilities of young men and women in the region are embraced, refined, and reinvest for the } \\
\text { Kingdom's renaissance. Furthermore, the Council sought to create a common mechanism and } \\
\text { an incubator environment to maintain a dialogue, interaction, and exchange experiences } \\
\text { among Saudi youth. Additionally, to express community issues, seek and implement the most } \\
\text { appropriate solutions and ideas for development, in line with the vision of the Kingdom } 2030 \text {. }\end{array}$ \\
\hline Vision & $\begin{array}{l}\text { They are investing in young people's abilities to be forearms men contributing to the Kingdom's } \\
\text { development. And sustainable community development. }\end{array}$ \\
\hline Message & $\begin{array}{l}\text { Foster and refine youth roles by developing a youth system that embraces creative ideas, invest } \\
\text { youth's energies in effective community participation, and makes tomorrow better. }\end{array}$ \\
\hline Objectives & $\begin{array}{l}\text { - They are promoting national values and pride in the Islamic identity among Saudi youth. } \\
\text { - They created a (United) space for young people to talk to decision-makers and offer creative } \\
\text { ideas and solutions. } \\
\text { - Investing in creative youth ideas and turning them into reality by developing relevant } \\
\text { initiatives and projects. } \\
\text { - Activating the pioneering role of youth in community participation and investing their talents } \\
\text { and capabilities. } \\
\text { - Adopting youth issues and concerns and placing them on the dialogue table before the } \\
\text { authorized person, proposing solutions, and working to achieve them. } \\
\text { - Young people contribute to national development to achieve the Kingdom's vision of 2030, } \\
\text { with its various orientations. }\end{array}$ \\
\hline $\begin{array}{l}\text { Functions of the } \\
\text { Council }\end{array}$ & $\begin{array}{l}\text { Services offered by the Council: Organizing activities and events, providing integrated services } \\
\text { for youth, embracing diverse youth talents, finding solutions to the most pressing problems, } \\
\text { activating youth participation in society, deepening giving and belonging values, sensitizing } \\
\text { youth to strengths and weaknesses, and fostering a spirit of competition and a love of collective } \\
\text { action }\end{array}$ \\
\hline $\begin{array}{l}\text { Conditions of } \\
\text { Council } \\
\text { membership }\end{array}$ & $\begin{array}{l}\text { - Be Saudi and resident in the region. } \\
\text { - Have experience in the field of youth and development work and be active in the social sphere. } \\
\text { - Have a good reputation. } \\
\text { - Not be a member of other councils, societies, or committees working in the same field and } \\
\text { the Council's activities. } \\
\text { - Be a believer in youth issues and their influential role in volunteer work. } \\
\text { - Be aware and believe in the importance of teamwork. } \\
\text { - Undertake to work for the Council and the public interest, away from personal interests and } \\
\text { self-benefits. }\end{array}$ \\
\hline
\end{tabular}

Source: Tabukyc, 2020 


\section{Table 4. Saudi-UAE Youth Council}

\begin{tabular}{|c|c|}
\hline dea & $\begin{array}{l}\text { The initiative "establishing the Saudi-UAE Youth Council" is an implementation of the } \\
\text { recommendations of the Saudi-UAE Coordination Council. On the Saudi side. It was chaired by } \\
\text { His Royal Highness Prince Mohammed bin Salman bin Abdul Aziz Al Saud, Crown Prince, Deputy } \\
\text { Prime Minister, Minister of Defense, and Chairman of the Council for Economic Affairs and } \\
\text { Development. O n the UAE side, chaired by his Highness Sheikh Mohammed bin Zayed Al } \\
\text { Nahyan, Crown Prince of Abu Dhabi, Deputy Commander-in-Chief of the Armed forces, and } \\
\text { Chairman of the Executive Council of Abu Dhabi, with ministers and officials from both } \\
\text { countries. Consequently, activate the Saudi-UAE youth's role in achieving the desired goals, the } \\
\text { Saudi-UAE Youth Council will deliver youth ideas to decision-makers from both countries. }\end{array}$ \\
\hline Vision & $\begin{array}{l}\text { They are creating a youth generation able to lead the future through a leadership environment } \\
\text { that fulfills young people's aspirations and enhances their abilities. }\end{array}$ \\
\hline Message & $\begin{array}{l}\text { They seek to empower young people to be a vital part of decision-making and future direction } \\
\text { through sustainable opportunities in the two countries' vision goals. }\end{array}$ \\
\hline Objectives & $\begin{array}{l}\text { - Stimulate youth partnerships and exchange ideas among them in both countries. } \\
\text { - Invest their vitality in different areas and sectors and contribute and effectively participate in } \\
\text { developing future scenarios. } \\
\text { - Encourages them to devise development initiatives to meet the challenges of the future. }\end{array}$ \\
\hline $\begin{array}{l}\text { Functions of the } \\
\text { Council }\end{array}$ & $\begin{array}{l}\text { The Council identified seven themes on which the Saudi-UAE Youth Council is based: (Tourism, } \\
\text { education, media, culture and art, entertainment, entrepreneurship, and health). }\end{array}$ \\
\hline $\begin{array}{l}\text { Conditions of } \\
\text { Council } \\
\text { membership }\end{array}$ & $\begin{array}{l}\text { The candidate is nominated by completing the member's data form and being a member's } \\
\text { nationality (Saudi, UAE) with the official papers attached, some initiatives suggested by the } \\
\text { member, and his participation in other youth councils. }\end{array}$ \\
\hline Executive & Its membership includes: \\
\hline Council & $\begin{array}{l}\text { - Her Excellency the Secretary of State for Youth Affairs of the United Arab Emirates. } \\
\text { - Assistant under-Secretary for Sustainable Development, } \\
\text { - Assistant Deputy-General for the G-2o. } \\
\text { - Ministry of Economy and Planning of Saudi Arabia. }\end{array}$ \\
\hline
\end{tabular}

Source: Saudi Emirati Youth, 2020

Table 5. British Youth Council

\begin{tabular}{|c|c|}
\hline Idea & $\begin{array}{l}\text { The State Department of the Government British established the British Youth Council in 1948, } \\
\text { after World War II. They aimed to unite young people in Britain versus the Communism forces. } \\
\text { In 1963, the British Youth Council resigned from the British government and became a charity } \\
\text { working to defend young people's views. In the late 196os, the Council's actual start-up had been } \\
\text { to include all local youth councils. More specifically, it has } 13 \text { Secretary-General representatives of } \\
\text { all the Council's governing bodies who meet six times a year. In 2010, it included more than } 500 \\
\text { councils and local youth organizations across the United Kingdom. Besides, it acts as a youth-led } \\
\text { charity to empower young people aged } 25 \text { and over without influence decisions that affect their } \\
\text { lives and supports them to engage in their communities and democratic life locally, nationally, } \\
\text { and internationally. }\end{array}$ \\
\hline Vision & $\begin{array}{l}\text { The British Youth Council is a world where every young man is empowered to make social and } \\
\text { political change. By 2021, then it will enable the youth to vote and make society better. }\end{array}$ \\
\hline Message & $\begin{array}{l}\text { As the U.K. National Youth Council brings young people together to voice and use them to } \\
\text { improve their lives, creating an environment where young people's views will be empowered in } \\
\text { the U.K. in general and in their communities in particular. }\end{array}$ \\
\hline Objectives & $\begin{array}{l}\text { - Helping other young people, regardless of their background or the obstacles they face, } \\
\text { makes the world a better place for everyone. } \\
\text { - } \quad \text { Empower young people aged } 25 \text { and under to influence decisions that affect their lives. } \\
\text { - nationally, and internationally. } \\
\text { - Making teams as volunteers, activists, decision-makers, and leaders. }\end{array}$ \\
\hline
\end{tabular}




\begin{tabular}{|c|c|}
\hline $\begin{array}{l}\text { Functions of } \\
\text { the Council }\end{array}$ & $\begin{array}{l}\text { - Determine needs and take action to claim them. } \\
\text { The members of Britain's Youth Council propose and vote on the organization's annual } \\
\text { election campaigns. } \\
\text { The British Youth Council provides resources, regional support, and coordination for } \\
\text { social actions for youth. }\end{array}$ \\
\hline $\begin{array}{l}\text { Conditions of } \\
\text { Council } \\
\text { membership }\end{array}$ & $\begin{array}{l}\text { - All youth-led organizations are members of the Council or those who serve young } \\
\text { people in the U.K. The members representing the Council shall be elected. } \\
\text { - All young people in the U.K. aged } 26 \text { and under are eligible to participate in the Council. }\end{array}$ \\
\hline
\end{tabular}

Source: BYC, 2016

\subsection{Fourth: Youth participation in government decision-making and the role of youth councils.}

Youth participation in political activities is identified explicitly in the decision-making process, as a subject not extensively studied by researchers in general (Augsberger et al., 2018), particularly in Saudi Arabia, where no study in the Kingdom addressed this idea. So, youth councils are a critical opportunity for all young people to benefit from various youth experiences. These inspiring models have managed to achieve accomplishments in all scientific and practical aspects. Youth councils are also a leading platform for sharing experiences and knowledge, empowering young people to look ahead and turn their challenges into opportunities in all areas. Therefore, youth participation in organized government enables the government to make optimal use of both youth and society's capacities, becoming more satisfied with their involvement in decision-making processes (Checkoway, 2011). Another point is that participation leads to a sense of self-esteem, enfranchising, and higher self-efficacy for young people (Blanchet-Cohen et al., 2014). The society also benefits when young people offer new ideas and solutions (Wong et al., 2010). Even though some forms of participation of young people are associated with their social class in society, as in American culture (Flanagan \& Levine, 2010). Consequently, Checkoway and Aldana (2013) identified youth councils as one of the most crucial government decision-making processes. Notably, Youth participation within the government may include specific strengths and weaknesses to both youth participants and the process of change.

Conner and Cosner (2016) compared young people participating in the government-approved youth committee against a community-based organization group to explore similarities and differences in youth civic commitments, their sense of the institution they represent, and their perceptions of social change. Despite the fact that the two youth groups considered themselves actors in the civil sphere and agents of change, The researchers concluded significant differences. For instance, young people who work in non-governmental organizations see that systematic change is needed more in their organizations to keep pace with their aspirations. In contrast, young people who work on government committees trust more government systems to keep up with their ambitions. Gordon and Taft (2011) points out that the Youth Council model is "highly state-centered," emphasizes debate, assumes state neutrality, and believes that diverse interests are adequately represented in the democratic process. More specifically, young people represented on local youth councils can draw government attention to related issues, organize forums, and advocate community-based policies and laws. The Checkoway, Allison, and Montoya study of the San Francisco Youth Commission in the United States showed in 2005.

\section{Previous Literature}

Many previous studies have been of youth importance, although many angles Analyze from one survey to another. (Collins et al., 2018) study aimed to identify the elements of youth councils' participation in the American capital and how social workers participated in the youth participation in these councils. The study monitored 36 active youth councils in the capital. The study concluded that most youth councils in the U.S. capital have many frameworks, structures, and systems for work, which may 
give flexibility, but at the same time may be a factor that deviates from the target of these councils or overlap in marks. It is recommended that the importance of establishing general structures, regulations, and charters for youth councils in the capital, the United States of America, ensuring its development. However, (Forde \& Martin, 2016) study addressed the right of children and young people to participate: National and local youth councils in Ireland, with a sample of 300 young people from Ireland. They spoke about their experience of participating in youth councils. The study concluded that the youth councils Ireland's success and providing opportunities for children and young people is to acquire skills and influence decision-making at the internal level. Still, the institutional and societal implications of their participation are less clear and influential. Additionally, the existing administrative structures of the Youth Councils of Ireland require legal guidelines and legislation throughout the state. In order to achieve the expected meaning and benefits of such participation.

(Collins et al., 2018) study examined the activities, impact, and constraints of local youth councils in Massachusetts and included youth councils in 24 major urban areas. The study results showed that youth councils participate in a wide range of activities that meet youth and the community's needs. In other words, some of these councils receive federal or state funding for these activities, and four significant constraints affect the operations of youth councils. For instance, officials are reluctant to involve young people in community problems and cultural and ethnic diversity in board members, which affects an assortment of interests. Besides, the community lacks the awareness of the importance of participating in these councils, non-uniformity in the practical and structural framework, or general framework charters at the state level. However, Seibert, Seal (2006) is a national youth councils survey worldwide, reached (22) boards. It aimed to discuss national youth councils in some countries regarding their origin, development, objectives, and governance methods. As a result, Youth organizations should be the actors behind the establishment of National youth councils. More specifically, to be a national youth council, and for the Council to work independently of the government, but in a youthful spirit and for the sake of youth in cooperation with organizations, charitable institutions, civil work organizations, or even various governmental bodies that wish to support youth organizations and support these councils through financial support or advice and guidance.

Although Matthews (2001) aimed to identify the great interest of the government, community, and civil society in fostering youth participation at the local level within the United Kingdom, it establishes youth councils. It is from a group of young people (3o young men) and (33 young women) perspective. The study results indicated that the U.K. viewed children and youth, mostly as incomplete citizens. Although they are granted protection rights and provision; However, they are deprived of political rights, so instead of participation is a right for them, it is presented as a privilege that only a privileged few of them are allowed. As a result, discourses within the U.K. community reduce the appropriateness or skepticism of political participation for children and youth or imbalance the form that the involvement and consequences should take. To sum up, the study also found six models of youth councils in the U.K., including Feeder Organizations, Shadow Organizations, Consultative Organizations, Group-Specific Organizations. Lastly, Community-Specific Organizations. (Matthews \& Limb, 1998) addressed development Youth Councils and Forums within the U.K. It dealt with the evolving nature of youth councils/forums across the U.K. as a diversity of roles characterized them. In the same context, the study confirmed that youth councils and meetings in Scotland and Northern Ireland have a better practice of these councils than the rest of the U.K. Moreover, the study showed that bodies supporting youth participation in these councils do not adopt a formal development strategy, i.e., the development of youth councils/forums in England was mostly random. Therefore, its growth in the Kingdom's various regions depended on demographics, political structures, area traditions, and the institutional and organizational structure. Furthermore, the study showed that stations to get youth representatives in each provincial Council and form youth parliament in Ireland.

Youth councils in the Kingdom regions are activation of youth roles in Saudi society. Hence, the youth 
councils in the Kingdom regions came up with a set of goals, including enhancing the belonging and citizenship of young people by activating their participation in the dialogues of social, economic, and cultural development in the region, take advantage of their proposals, capacities, and properties to provide innovative solutions to the challenges facing youth and the development process. In addition to involving young people in discussing and defining their requirements, contributing actively to their regions' development programs, in a way that does not conflict with established norms, religious values, public order, and systems, and engaging young people in decision-making, especially concerning their issues and concerns And their aspirations. Another critical point is that the councils aim to foster and frame young people to participate in volunteer work, serve the homeland, assume their responsibilities in helping their society and land, and establish a culture dialog, communication, and cooperation. Besides, to the growing organizational and institutional culture of youth, investing their time to develop their skills and abilities, and contributing to the preparation and creation of reliable national competencies in the future. In brief, these are the objectives of the draft regulation of the Area Youth Councils approved by the Shura Council in 2019 (Al-Malk, 2019).

Therefore, the study intended to affect the youth councils' role of citizenship development and effective participation in decision-making, only by having a unified legal entity supported and regulated by the boards. Furthermore, these councils' structure should be capable of effectiveness, organization, and application of the cooperative regulation approved by the Shura Council in 2019. More specifically, through a unified system of these councils or targeted structures, we can find a unified idiosyncrasy for youth councils in regions characterized by successful and institutional work. Thus, implement regulatory regulations to supervise the work within these institutions, by taking advantage of the actual board experiences in the regions or global affairs.

\subsection{Study Questions}

1. What is the optimal structure of youth councils from the youth perspective?

2. What are the objectives of youth councils from the youth perspective?

3. What are the tasks of youth councils from the youth perspective?

4. What are the terms for the membership of youth councils from the youth perspective?

5. What is the proposed vision of Saudi Arabia's youth councils?

\section{Methodology}

\subsection{Participants}

The Saudi youth study community at King Saud University in Riyadh, Saudi Arabia, has been the target of 61.321 students between 18 and 34 years of age, according to statistics from the University's Department of Statistics and Information, has been randomly selected as his representative for Saudi youth at King Saud University, consisting of 413 students.

\subsection{Procedures}

The competent authorities approved the study of King Saud University in Riyadh. The sample participants filled the questionnaire voluntarily without any pressure. Hence, the questionnaire was distributed to the 413 students participating in this study to ensure confidentiality. Students have completed the questionnaire on the website via e-mail and Whatsapp.

\subsection{Measurements}

In the current study, after reviewing the literature on youth councils and the nature of their structure, tasks, goals, and membership conditions, the researchers prepared a questionnaire consisting of two 
parts: the first part includes the sample study's demographic data. In contrast, the second part covers the three main research areas: the first axis, which contains the optimal structural terms of youth councils in Saudi Arabia, consists of (8) phrases. The second axis, has youth councils objectives, consists of (10) phrases. Finally, the third axis, includes youth councils functions, consists of (15) phrases.

The five-point Likert scale (strongly agree - ok - neutral - disagree - strongly disagree) has been used. Scores were distributed from 1 to 5 , one for "strongly agree" and five for "strongly agree"; the Cronbach Alpha values for the three dimensions were calculated and were $0.811,0.958,0.965$, and the scale, as a whole was 0.962 .

\subsection{Data analysis}

Several appropriate statistical methods have been used. For example, we are calculating repetitions, percentages, arithmetic mean, and standard deviation. As a result, they can identify how individual study responses to each resolution axis statement are skewed and answer study questions. Moreover, Alpha-Cronbach's Alpha coefficient was used to calculate the tool's stability during the Statistical Package for the Social Sciences-SPSS-19 program.

\section{Results}

The study axes were analyzed to extract its results according to its various questions, and the results were as follows:

\subsection{The first question answer: About the optimal structure of youth councils from the youth perspective}

Table 6. Results of the sample study views on boards Young people's best-structured statements rank according to the arithmetic mean

\begin{tabular}{|c|c|c|c|c|c|c|c|c|c|c|c|c|c|}
\hline \multirow[t]{2}{*}{ Phrases } & \multicolumn{2}{|c|}{$\begin{array}{l}\text { Strongly } \\
\text { agree }\end{array}$} & \multicolumn{2}{|c|}{ agree } & \multicolumn{2}{|c|}{$\begin{array}{l}\text { I don't } \\
\text { know }\end{array}$} & \multicolumn{4}{|c|}{$\begin{array}{r}\text { Disagree Strongly } \\
\text { disagree }\end{array}$} & \multirow[t]{2}{*}{$\begin{array}{c}\text { Arithmetic } \\
\text { mean* }\end{array}$} & \multirow[t]{2}{*}{$\begin{array}{l}\text { Standard } \\
\text { deviation }\end{array}$} & \multirow[t]{2}{*}{ Order } \\
\hline & $\mathrm{n}$ & $\%$ & $\mathrm{n}$ & $\%$ & $\mathrm{n}$ & $\%$ & $\mathrm{n}$ & $\%$ & $\mathrm{n}$ & $\%$ & & & \\
\hline $\begin{array}{l}\text { Forms internal committees in the } \\
\text { Council that undertake different tasks } \\
\text { (media, cultural, social). }\end{array}$ & 190 & 46 & 142 & 34.4 & 76 & 18.4 & 5 & 1.2 & o & o & 4.25 & 0.79 & 1 \\
\hline $\begin{array}{l}\text { The Council is directly subordinate to } \\
\text { the Emirate of the region or the } \\
\text { province. }\end{array}$ & 148 & 35.8 & 165 & 40 & 85 & 20.6 & 11 & 2.7 & 4 & 1 & 4.07 & o.87 & 2 \\
\hline $\begin{array}{l}\text { Sub-councils are formed in the } \\
\text { provinces of the regions. }\end{array}$ & 107 & 25.9 & 187 & $45 \cdot 31$ & 102 & 24.7 & 12 & 2.9 & 5 & 1.2 & 3.92 & 0.85 & 3 \\
\hline $\begin{array}{l}\text { The Council is linked to other councils } \\
\text { in the region (district Council, } \\
\text { municipal councils, local councils). }\end{array}$ & 99 & 24 & 132 & 321 & 150 & 36.3 & 28 & 6.8 & 4 & 1 & 3.71 & 0.94 & 4 \\
\hline $\begin{array}{l}\text { A faculty member in the university is } \\
\text { the Secretary-general of the Council. }\end{array}$ & 96 & 23.2 & 160 & 37.71 & 108 & 26.2 & 34 & 8.2 & 15 & 3.6 & 3.7 & 1.03 & 5 \\
\hline $\begin{array}{l}\text { The region's prince or governor heads } \\
\text { the Council. }\end{array}$ & 106 & 25.7 & 148 & 35.8 & 89 & 21.5 & 53 & 12.8 & 17 & 4.1 & 3.66 & 1.12 & 6 \\
\hline $\begin{array}{l}\text { The Director of the University } \\
\text { (Member of the Council of the region) } \\
\text { is a Vice-President of the Council. }\end{array}$ & 82 & 19.9 & 137 & 33.21 & 140 & 33.9 & 40 & $9 \cdot 7$ & 14 & 3.4 & 3.65 & 1.02 & 7 \\
\hline $\begin{array}{l}\text { The membership of the Council } \\
\text { between males and females should be } \\
\text { equal. }\end{array}$ & 117 & 28.3 & 104 & 25.21 & 106 & 25.7 & 63 & $15 \cdot 3$ & 23 & 5.6 & 3.55 & 1.21 & 8 \\
\hline General average & & & & & & & & & & & 3.80 & 0.978 & \\
\hline
\end{tabular}


From Table 6 it is clear that a sample has an approval Study of young people around the optimal structural axis of youth councils, by an average ( 3.80 of 5 ), that is, "agree." This axis is eight phrases about the optimal structure of these councils, and the standard of these terms ranged from 4.25 to 3.55 of 5 degrees, between strongly agree and agree. More specifically, the phrase "internal committees in the Council that undertake the various tasks: Media, Cultural, Social" came in the first place, with a mean of (4.25). That is, strongly agree, with a small standard deviation of 0.79. Thus, The phrase " The Council is directly subordinate to the Emirate of the region or the province" is in second place, with a mean of (4.07), that is, "agree" only. However, the rest of this axis varied, as the phrase "The membership of the Council between males and females should be equal" is eighth and last, with an average of (3.55), that is, "agree" only, but with a significant standard deviation of 1.21, the study sample's views on the phrase were different, but mostly "agree."

\subsection{The second question answer: About the objectives of youth councils from the youth perspective}

Table 7. Study sample results for axis phrases of Youth Council goals, ranked by the mean

\begin{tabular}{|c|c|c|c|c|c|c|c|c|c|c|c|c|c|}
\hline \multirow[t]{2}{*}{ Phrases } & \multicolumn{2}{|c|}{$\begin{array}{l}\text { Strongly } \\
\text { agree }\end{array}$} & \multicolumn{2}{|c|}{ Agree } & \multicolumn{2}{|c|}{$\begin{array}{l}\text { I don't } \\
\text { know }\end{array}$} & \multicolumn{2}{|c|}{ disagree } & \multicolumn{2}{|c|}{$\begin{array}{l}\text { Strongly } \\
\text { disagree }\end{array}$} & \multirow[t]{2}{*}{$\begin{array}{l}\text { Arithmetic } \\
\text { mean* }^{*}\end{array}$} & \multirow[t]{2}{*}{$\begin{array}{l}\text { Standard } \\
\text { deviation }\end{array}$} & \multirow[t]{2}{*}{ Order } \\
\hline & $\mathrm{n}$ & $\%$ & $\mathrm{n}$ & $\%$ & $\mathrm{n}$ & $\%$ & $\mathrm{n}$ & $\%$ & $\mathrm{n}$ & $\%$ & & & \\
\hline $\begin{array}{l}\text { Take advantage of youth proposals, } \\
\text { capacities, and intellectual } \\
\text { property. }\end{array}$ & 296 & 71.7 & 92 & 22.3 & 21 & 5.1 & 3 & 0.7 & 1 & 0.2 & 4.64 & 0.64 & 1 \\
\hline $\begin{array}{l}\text { Deepen the trust of young people } \\
\text { themselves and in their society. }\end{array}$ & 287 & 69.5 & 99 & 24.02 & 22 & $5 \cdot 3$ & 4 & 1.0 & 1 & 0.2 & 4.62 & 0.66 & 2 \\
\hline $\begin{array}{l}\text { Young people should participate in } \\
\text { the discussion and determination } \\
\text { of their requirements. }\end{array}$ & 292 & 70.7 & 89 & 21.5 & 26 & 6.3 & 5 & 1.2 & 1 & 0.2 & 4.61 & 0.68 & 3 \\
\hline $\begin{array}{l}\text { Pay young people their } \\
\text { responsibilities in the service of } \\
\text { their community and home. }\end{array}$ & 275 & 66.6 & 114 & 27.6 & 20 & 4.8 & 2 & 0.5 & 2 & 0.5 & $4 \cdot 59$ & 0.65 & 4 \\
\hline $\begin{array}{l}\text { Establish a culture of dialog and } \\
\text { cooperation among youth in the } \\
\text { interest of the nation. }\end{array}$ & 179 & 67.6 & 104 & 25.2 & 23 & 5.6 & 5 & 1.2 & 2 & 0.5 & $4 \cdot 58$ & 0.70 & 5 \\
\hline $\begin{array}{l}\text { Invest youth times to develop their } \\
\text { skills and abilities. }\end{array}$ & 285 & 69.0 & 93 & 22.5 & 25 & 6.1 & 8 & 1.9 & 2 & 0.5 & $4 \cdot 58$ & 0.74 & 5 \\
\hline $\begin{array}{l}\text { Foster and frame youth } \\
\text { participation in volunteer work for } \\
\text { the nation. }\end{array}$ & 275 & 66.6 & 104 & 25.2 & 27 & 6.5 & 6 & 1.5 & 1 & 0.2 & $4 \cdot 56$ & 0.70 & 6 \\
\hline $\begin{array}{l}\text { Participate in their regions' } \\
\text { development programs in a manner } \\
\text { that does not conflict with religious } \\
\text { principles, values, public order, or } \\
\text { established systems. }\end{array}$ & 267 & 64.6 & 108 & 26.2 & 33 & 8.0 & 3 & 0.7 & 2 & 0.5 & $4 \cdot 54$ & 0.72 & 7 \\
\hline $\begin{array}{l}\text { Promote the belonging and } \\
\text { citizenship of young people. }\end{array}$ & 254 & 61.5 & 129 & 31.2 & 26 & 6.3 & 4 & 1.0 & o & 0.0 & $4 \cdot 35$ & 0.66 & 8 \\
\hline $\begin{array}{l}\text { Young people should participate in } \\
\text { decision-making, particularly } \\
\text { concerning their issues. }\end{array}$ & 257 & 62.2 & 111 & 26.9 & 30 & $7 \cdot 3$ & 11 & 2.7 & 4 & 1.0 & 4.47 & 0.82 & 9 \\
\hline General average & & & & & & & & & & & 4.75 & 597 & \\
\hline
\end{tabular}

From Table 7 it is clear that there has been strong approval of the study sample of young people on the center of youth councils' goals by an average ( 4.57 of 5 ), that is, strongly agree. This axis is nine phrases about councils' objectives, the standard of these terms ranged from 4.64 to 4.47 of 5 degrees, all of which are strongly agreed. More specifically, The phrase " Take advantage of youth proposals, 
capacities, and intellectual property." came in the first place, with a mean of (4.64). That is, strongly agree, with a small standard deviation of o.64. However, the rest of this axis varied, as the phrase " Young people participate in decision-making, particularly concerning their issues" is last, with an average of (4.47). That is, strongly agree, but with a small standard deviation of 0.82 , which shows that there is no significant difference between the sample study views on this phrase.

\subsection{The third question answer: About the tasks of youth councils from the youth perspective}

Table 8. Study sample results for axis statements Functions of youth councils are arranged according to the mean

\begin{tabular}{|c|c|c|c|c|c|c|c|c|c|c|c|c|c|}
\hline \multirow[t]{2}{*}{ Phrases } & \multicolumn{2}{|c|}{$\begin{array}{l}\text { Strongly } \\
\text { agree }\end{array}$} & \multicolumn{2}{|c|}{ Agree } & \multicolumn{2}{|c|}{$\begin{array}{l}\text { I don't } \\
\text { know }\end{array}$} & \multicolumn{4}{|c|}{$\begin{array}{r}\text { Disagree Strongly } \\
\text { disagree }\end{array}$} & \multirow[t]{2}{*}{$\begin{array}{l}\text { Arithmetic } \\
\text { mean* }\end{array}$} & \multirow[t]{2}{*}{$\begin{array}{l}\text { Standard } \\
\text { deviation }\end{array}$} & \multirow[t]{2}{*}{ Order } \\
\hline & $\mathrm{n}$ & $\%$ & $\mathrm{n}$ & $\%$ & $\mathrm{n}$ & $\%$ & $\mathrm{n}$ & $\%$ & $\mathrm{n}$ & $\%$ & & & \\
\hline $\begin{array}{l}\text { Encourage creative and talented young } \\
\text { people to make national achievements } \\
\text { to serve the community. }\end{array}$ & 286 & 69.2 & 93 & 22.5 & 26 & 6.3 & 6 & 1.5 & 2 & 0.5 & $4 \cdot 59$ & 0.72 & 1 \\
\hline $\begin{array}{l}\text { Motivate young people to take on their } \\
\text { responsibilities in serving their } \\
\text { community and home. }\end{array}$ & 272 & 65.9 & 109 & 26.4 & 25 & 6.1 & 4 & 1.0 & 3 & 0.7 & 4.56 & 0.72 & 2 \\
\hline $\begin{array}{l}\text { Promote national belonging among } \\
\text { young people. }\end{array}$ & 267 & 64.6 & 117 & 28.3 & 20 & 4.8 & 7 & 1.7 & 2 & 0.5 & $4 \cdot 55$ & 0.71 & 3 \\
\hline $\begin{array}{l}\text { Contribute to empowering young } \\
\text { people to play an active role in society. }\end{array}$ & 253 & 61.3 & 126 & 30.5 & 32 & $7 \cdot 7$ & 1 & 0.2 & 1 & 0.2 & $4 \cdot 5^{2}$ & 0.67 & 4 \\
\hline $\begin{array}{l}\text { Contribute to building national } \\
\text { competencies with a view to their future } \\
\text { reliance. }\end{array}$ & 254 & 61.2 & 125 & 30.3 & 28 & 6.8 & 3 & 0.7 & 3 & 0.7 & $4 \cdot 51$ & 0.72 & 5 \\
\hline $\begin{array}{l}\text { Promote a culture of dialog and } \\
\text { communication among young people by } \\
\text { all means. }\end{array}$ & 263 & 63.7 & 112 & 27.1 & 27 & 6.5 & 6 & 1.5 & 5 & 1.2 & $4 \cdot 51$ & 0.78 & 5 \\
\hline $\begin{array}{l}\text { Monitor the needs and concerns of } \\
\text { youth. }\end{array}$ & 252 & 61.0 & 125 & 30.3 & 29 & 7.0 & 4 & 1.0 & 3 & 0.7 & $4 \cdot 50$ & 0.73 & 6 \\
\hline $\begin{array}{l}\text { Develop action plans for the } \\
\text { implementation of youth activities and } \\
\text { programs. }\end{array}$ & 247 & 59.8 & 131 & 31.7 & 31 & $7 \cdot 5$ & 3 & 0.7 & 1 & 0.2 & $4 \cdot 50$ & 0.69 & 6 \\
\hline $\begin{array}{l}\text { Build a link between youth and } \\
\text { decision-makers. }\end{array}$ & 254 & 61.5 & 116 & 28.1 & 37 & 9.0 & 3 & 0.7 & 3 & 0.7 & 4.49 & 0.75 & 7 \\
\hline $\begin{array}{l}\text { Enhance the contribution of young } \\
\text { people to decision-making on their } \\
\text { aspirations. }\end{array}$ & 254 & 61.5 & 122 & 29.5 & 27 & 6.5 & 7 & 1.7 & 3 & 0.7 & 4.49 & 0.76 & 7 \\
\hline $\begin{array}{l}\text { Adopt proposals and projects for young } \\
\text { people that meet their needs. }\end{array}$ & 244 & 59.1 & 130 & 31.5 & 33 & 8.0 & 5 & 1.2 & 1 & 0.2 & 4.48 & 0.72 & 8 \\
\hline $\begin{array}{l}\text { Supervise and propose appropriate } \\
\text { solutions to youth issues and problems. }\end{array}$ & 251 & 60.8 & 121 & 29.3 & 29 & 7.0 & 7 & 1.7 & 5 & 1.2 & 4.47 & 0.80 & 9 \\
\hline $\begin{array}{l}\text { Propose appropriate mechanisms to } \\
\text { activate young people's visions and } \\
\text { aspirations. }\end{array}$ & 237 & $57 \cdot 4$ & 135 & 32.7 & 37 & 9.0 & 3 & 0.7 & 1 & 0.2 & $4 \cdot 46$ & 0.71 & 10 \\
\hline $\begin{array}{l}\text { Determine the use of dialog as a } \\
\text { problem-solving mechanism. }\end{array}$ & 242 & 58.6 & 127 & 30.8 & 34 & 8.2 & 7 & 1.7 & 3 & 0.7 & 4.45 & 0.78 & 11 \\
\hline Provide youth advisory services. & 236 & $57 \cdot 1$ & 131 & 31.7 & 39 & $9 \cdot 4$ & 6 & 1.5 & 1 & 0.2 & 4.44 & 0.74 & 12 \\
\hline General average & & & & & & & & & & & $4 \cdot 50$ & 0.733 & \\
\hline
\end{tabular}

From Table 8 it is clear that there has been strong approval of the study sample of young people on the center of youth councils' tasks by an average (4.5 of 5). That is, strongly agree. This axis is twelve phrases about councils' functions, the standard of these terms ranged from 4.59 to 4.44 of 5 degrees, all of which 
are strongly agreed. More specifically, The phrase "Encourage creative and talented young people to make national achievements to serve the community" came in the first place, with a mean of (4.59), That is, strongly agree, with a small standard deviation of 0.72 . However, the rest of this axis was varied, as the phrase "Provide youth advisory services." is last, with an average of (4.44), that is, strongly agree, but with a small standard deviation of 0.74 , which shows that there is no significant difference between the sample study views on this phrase.

5.4 The question four answer: About the terms for the membership of youth councils from the youth perspective

Table 9. Study sample results about terms of axis membership of youth councils

\begin{tabular}{llcc}
\hline Variant & & $\mathrm{n}$ & $\%$ \\
\hline 1. Minimum age of Council Member: & Under 16 years old & 23 & $5.6 \%$ \\
& $16-17$ years old & 65 & $\mathbf{1 5 . 7} \%$ \\
& 18 years and over & 315 & 76.3 \\
2. Maximum age of Council Member & 25 & 36 & $8.7 \%$ \\
& 30 & 18 & $67.6 \%$ \\
& Over 3o & 98 & $23.7 \%$ \\
3. Term: & A year & 151 & $36.6 \%$ \\
& Two years & 156 & $37.8 \%$ \\
& Three years & 52 & $12.6 \%$ \\
& Four years & 40 & $9.7 \%$ \\
4. Members are nominated by government educational & Else & $\mathbf{1 4}$ & $3.4 \%$ \\
bodies (education and university departments). & Disagree & 320 & $77.5 \%$ \\
5. The Ministry of Interior appoints members. & Agree & 93 & $\mathbf{2 2 . 5} \%$ \\
& Disagree & $\mathbf{2 7 6}$ & $66.8 \%$ \\
6. Permanent residence is required in the Council's & Agree & 137 & $33.2 \%$ \\
region or province. & Disagree & $\mathbf{2 9 7}$ & $71.9 \%$ \\
& total & $\mathbf{1 1 6}$ & $\mathbf{2 8 . 1} \%$ \\
& & 413 & $\mathbf{1 0 0} \%$ \\
\hline
\end{tabular}

Table 9 shows a diversity of opinions about the Council's minimum membership, but those aged 18 years and over got the largest percentage of $76.3 \%$. While $15.7 \%$ suggested that the membership should be 16 or 17 years, and a lower sample study rate supported that the membership below this age should be $5.6 \%$ of the sample study. Meanwhile, the maximum for membership was $67.6 \%$ for those who reached 30 years, $23.7 \%$ allows those over 30 years to join the membership, and $8.7 \%$ said that the maximum age for membership is 25 years.

The study sample opinions have been diversified on the term of membership. $37.8 \%$ showed that membership should be two years, while $36.6 \%$ supported it to be one year, and the rest of the membership terms came in lower rates. However, the study sample endorsed the suggestion that members from governmental, educational bodies (departments of education and universities) be nominated by $77.5 \%$. In comparison, $66.8 \%$ supported the idea that members were appointed by the Ministry of Interior decision, and $71.9 \%$ supported permanent residence in the Council region or governorate for membership. 
5.5 The fifth question answer: About the proposed vision of Saudi Arabia's youth councils, according to the study results

Table 1o. a proposed scenario for Saudi Arabia Arabia's youth councils according to the study results

The ideal structure for youth councils in the Kingdom

Objectives of youth councils

Functions of Youth Councils

Conditions of youth councils membership
- The district's governor chairs the Council.

- The Director of the University (Member of the Council of the region) is a VicePresident of the Council.

- Set up internal committees in the Council to undertake various tasks (media, cultural, and social).

- The Council is directly subordinate to the Emirate of the region or the province.

- Sub-councils are formed in the provinces.

- The Council is linked to other councils in the region (the District Council, the Municipal Councils, and the Local Councils).

- A faculty member at the university is Secretary-General.

- The Council should have equal male and female membership.

- Take advantage of youth proposals, capacities, and intellectual property.

- Deepen the trust of young people themselves and in their society.

- Young people should participate in the discussion and determination of their requirements.

- Pay young people their responsibilities in the service of their community and home.

- Establish a culture of dialog and cooperation among youth in the interest of the nation.

- Invest youth times to develop their skills and abilities.

- Foster and frame youth participation in volunteer work for the nation.

- Promote the belonging and citizenship of young people.

- Young people should participate in decision-making, particularly concerning their issues.

- Encourage creative and talented young people to make national achievements to serve the community.

- Motivate young people to take on their responsibilities in serving their community and home.

- Promote national belonging among young people.

- Contribute to empowering young people to play an active role in society.

- Contribute to building national competencies with a view to their future reliance.

- Monitor the needs and concerns of youth.

- Develop action plans for the implementation of youth activities and programs.

- Build a link between youth and decision-makers.

- Enhance the contribution of young people to decision-making on their aspirations.

- Adopt proposals and projects for young people that meet their needs.

- Supervise and propose appropriate solutions to youth issues and problems.

- Propose appropriate mechanisms to activate young people's visions and aspirations.

- Determine the use of dialog as a problem-solving mechanism.

- Provide youth advisory services.

The terms of the Council's membership are as follows:

First: Members are between the ages of 18 and 30 .

Second: The office term shall be two years, and the President shall have the authority to reaffirm the membership for a second term, provided that the official term of a member shall not exceed four years.

Third: Members are nominated by government educational bodies (departments of education and universities).

Fourth: Members are appointed by the Ministry of Interior decision.

Fifth: The permanent residence of a member is required in the Council's region or province. 
Table 10 illustrates the proposed vision of Saudi Arabia's youth councils, according to the study results, in terms of the optimal structure of youth councils in the Kingdom, youth councils' objectives, youth functions councils, and the terms of youth councils membership.

\section{Discussion}

Saudi Arabia faces many economic, social, and educational challenges. For this reason, the Kingdom has launched its vision of 2030, which needs to mobilize all the society's energies to achieve them. One of the most important of these energies is the youth group, aged 15-34 years, and depends a lot to achieve the vision. Therefore, we call for young people's participation in decision-making, activating their role in achieving the homeland's concept (government, 2020). Besides, the establishment of youth councils contributes to enhancing the belonging and citizenship of young people by starting their participation in dialogues of social, economic, and cultural development in the region, and benefit from their proposals, energies, and individual capabilities in providing innovative solutions to the challenges facing them and the country's development process(USAID \& EQUIP 3 , 2009). Hence, This study aimed to identify the optimal structure for youth councils in the Kingdom of Saudi Arabia, to lay down the necessary regulations for these councils by defining the objectives, tasks, and membership conditions, and to develop a unified proposed vision for these councils. The results showed that the proposed structure of youth councils was approved from their perspective. More specifically, it strongly agreed that there would be internal committees in the Council to undertake the different tasks, and it would be directly related to the region or the governorate. In addition to forming sub-councils in the region's governorates, with each region's Council linked to the other councils, the suggestion was approved that a member of the region's university faculty should be Secretary-general, and the university management's membership to be a vice-president of the Council. The regional or conservative prince heads the Council, and there is an equality in the number of Council members between males and females.

Another critical point is that the study results showed strong approval of all targets presented to youth councils in the regions from the study sample perspective. Remarkably, these councils' most important goals were strongly approved to benefit from the youth's suggestions, capacities, and intellectual properties. It will deepen young people's confidence in themselves and their society, involve them in discussing and defining their requirements, and pushing them to assume their responsibilities in serving their community and homeland. Moreover, it will establish the dialog culture and cooperation among youth in the nation's interest, invest their time to develop their skills and abilities, promote and frame their participation in volunteer work for the country. Also, contribute effectively to their regions' development programs, in a way that does not conflict with the principles, religious values, public order, or the established regimes. For this reason, they should promote belonging and citizenship and their participation in decision-making, particularly concerning their issues.

Another contributing factor is that the results showed strong approval of all youth councils' proposal functions in the Kingdom from the sample study perspective. Whereby it strongly agreed that one of these councils' tasks is to encourage creative and talented young people. As a result, they achieve national achievements, motivate them to take on their responsibilities in serving their community. In a nutshell, it will strengthen the national belonging of young people. Besides, empower youth to play an active role in society, build national competencies for future dependence, and enhance the dialogue culture and communication among youth by all means. Another task that has been strongly agreed is to have a role in monitoring the needs and concerns of youth, supervising youth issues and problems and proposing appropriate solutions, developing action plans for the implementation of youth activities and programs, building a link between youth and decision-making, and proposing proper mechanisms to give effect to youth views and aspirations. In a nutshell, this reinforces young people's contribution to decision-making on their ambitions by adopting youth proposals and projects that meet their needs. 
Incidentally, the councils play a role in establishing dialog to solve problems, especially youth, and provide advisory services for them. The results also showed agreement that the membership is for those who are 18 years and over. Meanwhile, the upper age limit for membership is 30 years. Besides, The official term should be one or two years, and the Ministry of the Interior decision should nominate the members of government educational bodies (departments of education and universities). In addition to the permanent residence condition in the Council's region or governorate for membership in the Council.

All in all, one of the most essential proposed concepts of youth councils in Saudi Arabia is to activate youth in society through their outreach and development, strengthen their citizenship and belonging, in order to benefit from their abilities, suggestions, capacities, intellectual property, deepen confidence in themselves and their society, and be representatives of different communities, ages and backgrounds in society. Significantly, this contributes to coming up with creative ideas, effective policies, and fruitful proposals that positively affect society as a whole, and support the nation's march to achieve progress in social, economic, commercial, cultural and intellectual aspects. Consequently, the youth role in society can be activated, their problems solved, their issues identified without engaging them with the issues and topics that concern them, listening to and encouraging them, and talking directly with them. The idea of creating youth councils is unique to ignite their enthusiasm first, as well as to be viable and develop as a new experience in society, to be a gateway for outstanding success, a bright future, and an advancement of society.

\section{Conclusions and recommendations}

The current study tried to tackle the problem of youth councils in Saudi Arabia, by discussing the current situation of these councils and discussing the structure, tasks, goals and membership conditions that young people from King Saud University students face. Lastly, the study has reached a series of actual results in addition to a suggested idea. Hence, the research is considered one of the new studies inside the Kingdom regarding youth and social service councils. Therefore, it is the beginning of a path to a series of subsequent studies, through which this subject is dealt with in different comprehensive dimensions in other regions of the Kingdom, additional samples of society and not just youth. As a result of the importance of these councils and their relationship to social service, it should be the beginning of a path for researchers too.

It is recommended that there should be a body responsible for organizing work and structuring of youth councils in the regions, implementing the proposed vision of youth councils in Saudi Arabia for practical application to youth councils in areas that have been or are to be established. In addition to increasing the joint youth councils handled by the Saudi-Emirates Youth Council, because of its augmented cultural exchange and interaction between youth and improving the position of youth councils in the Kingdom. Hence, apply interactive activities and meetings between youth councils across regions annually or periodically, to exchange experiences and improve performance. Lastly, the Ministry of Communications and Information Technology in the Kingdom has adopted the establishment of a joint interactive electronic portal for these councils, which is to be distributed to each Council. Therefore, there is a compatible electronic channel for these councils, which allows accessible communication between youth in the areas, and to form the nucleus of a local social communication portal to discuss the most critical regional issues interregional interest and transfer of expertise.

\section{Acknowledgements}

The authors would like to thank the Centre for Promising Research in Social Research and Women's Studies Deanship of Scientific Research at Princess Nourah bint Abdulrahman University in Kingdom of Saudi Arabia for funding this Project in 2020. 


\section{References}

Akiva, T., Cortina, K. S., \& Smith, C. (2014). Involving youth in program decision-making: How common and what might it do for youth? Journal of Youth and Adolescence, 43(11), 1844-186o.

Al-Azmi, A. R. (2019). The Shura Council approves the project of the Regional Youth Councils. SABQ electronic newspaper. https://sabq.org/

Al-Malk, J. (2019). District councils promote the role of youth in decision-making. Almadina https://www.almadina.com/article/608081

Al-Rasheed, M. (2017). Establish youth councils. Mal Economic Newspaper. https://www.maaal.com/archives /20171127/99859

Al-Sharari, H. A.-W. (2017). Regional youth councils ... the Emirati experience as an example. Al Jazeera.

Augsberger, A., Collins, M. E., Gecker, W., \& Dougher, M. (2018). Youth civic engagement: Do youth councils reduce or reinforce social inequality? Journal of Adolescent Research, 33(2), 187-208.

Blanchet-Cohen, N., Manolson, S., \& Shaw, K. (2014). Youth-led decision making in community development grants. Youth E Society, 46(6), 819-834.

BYC. (2016). British Youth Council https://doi.org/https://www.byc.org.uk/

Checkoway, B. (2011). What is youth participation? Children and youth services review, 33(2), 340-345.

Checkoway, B., \& Aldana, A. (2013). Four forms of youth civic engagement for diverse democracy. Children and youth services review, 35(11), 1894-1899.

Collins, M. E., Augsberger, A., \& Gecker, W. (2018). Identifying Practice Components of Youth Councils: Contributions of Theory. Child and Adolescent Social Work Journal, 35(6), 599-610.

Conner, J. O., \& Cosner, K. (2016). Youth change agents: Comparing the sociopolitical identities of youth organizers and youth commissioners. Democracy and Education, $24(1), 2$.

Flanagan, C., \& Levine, P. (2010). Civic engagement and the transition to adulthood. The future of children, 159-179.

Forde, C., \& Martin, S. (2016). Children and young people's right to participate: National and local youth councils in Ireland. The International Journal of Children's Rights, 24(1), 135-154.

Gordon, H. R., \& Taft, J. K. (2011). Rethinking youth political socialization: Teenage activists talk back. Youth $\mathcal{E}$ Society, 43(4), 1499-1527.

[Record \#6 is using a reference type undefined in this output style.]

Jostyn, J. (1945). The Manhasset youth council. The Journal of Educational Sociology, 18(7), 417-425.

Jouf. (2020). Al-Jouf Youth Council https://doi.org/https://www.aljoufyc.com/

Martin, S., Pittman, K., Ferber, T., \& McMahon, A. (2007). Building Effective Youth Councils: A Practical Guide To Engaging Youth In Policy Making. Forum for youth investment,

Matthews, H. (2001). Citizenship, youth councils and young people's participation. Journal of youth studies, 4(3), 299-318.

Matthews, H., \& Limb, M. (1998). The right to say: the development of youth councils/forums within the UK. Area, 30(1), 66-78.

Muhammad, M. J. A. (2014). The Role of Human Development Programs in Improving the Quality of Life for University Youth: A Study Applied on Graduates of the Roads Leading to Higher Education Project in Aswan Governorate. Journal of Studies in Social Work and Human Sciences, Helwan University, 36(4), 1385-1468.

Nairn, K., Sligo, J., \& Freeman, C. (2006). Polarizing participation in local government: Which young people are included and excluded? Children Youth and Environments, 16(2), 248-271.

SaudiEmiratiYouth. (2020). Saudi-UAE Youth Council https://doi.org/https://saudiemiratiyouth.com/en

Seibert, C. K., \& Seale, F. (2006). National Youth Councils: Their Origin, Development, Objectives, and Governance Methods. Beirut, Lebanon.

Tabukyc. (2020). Tabuk region Youth Council https://tabukyc.org.sa/

USAID, \& EQUIP3. (2009). Youth Councils: An Effective Way to Promote Youth Participation : Some Initial Findings from Africa. US Agency for International Development. https://www.youthpower.org/

Wong, N. T., Zimmerman, M. A., \& Parker, E. A. (2010). A typology of youth participation and empowerment for child and adolescent health promotion. American journal of community psychology, 46(1), 100-114. 